Pamiętnik Literacki 2019, 4, s. 181-195

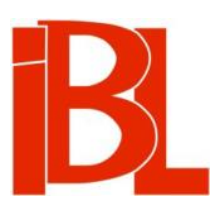

\title{
Praktykowanie uważności i kultura ascezy. O Józefie Czapskim
}

\author{
Magdalena Popiel
}


Pamiętnik Literacki CX, 2019, z. 4, PL ISSN 0031-0514

DOI: $10.18318 / \mathrm{pl} .2019 .4 .13$

MAGDALENA POPIEL Uniwersytet Jagielloński, Kraków

PRAKTYKOWANIE UWAŻNOŚCI I KULTURA ASCEZY

O JÓZEFIE CZAPSKIM

Miałem ów bezcenny dar skupienia $[\ldots]^{1}$.

Niektóre słowa funkcjonując w odmiennych językach, czasie i miejscu, osiagają różne stany skupienia - to rozrzedzają się, to gęstnieją. W pewnych okresach wypełniają się banałem znaczenia albo przeciwnie: niespodziewanie nabierają kulturowego ciężaru, jakby rozpoczynając proces fermentacji, zyskuja smak, bogactwo sensów, aromat odcieni emocjonalnych. Ta dość oczywista konstatacja staje się, jak sądzę, bardziej interesująca, gdy przyjrzymy się konkretnym przypadkom i określimy parametry, poprzez które wyraźniej uwidacznia się partykularność tego zjawiska. Rozmaite stany skupienia słów można śledzić nie tylko w procesie rozwoju danego języka czy też w odmiennych geokulturowych obszarach. Intrygujące bywają synchroniczne rozgałęzienia obiegu słów docierające do krańcowo różnych zakątków kultury - ten fenomen stał się doskonale widoczny w ostatnim stuleciu. Jednym $z$ takich słów jest „uważność”.

„Uważność”/,uwaga” należą do języka potocznego i ta przestrzeń ich funkcjonowania stanowi stały kontekst dla wielu obiegów w kulturze. Wspomina o tym Zofia Król w książce Powrót do świata. Dzieje uwagi w filozofii i literaturze XX wie$k u$, będącej pierwszą na polskim gruncie próbą syntezy poglądów i poetyk istotnych dla pojęcia uważności ${ }^{2}$. Przywołanie Henriego Bergsona, Edmunda Husserla, Martina Heideggera i przede wszystkim Maurice'a Merleau-Ponty'ego można potraktować jako propozycję konstruowania filozoficznej tradycji problematyki uważności. Sytuacja w literaturze, w szczególności polskiej, jest trochę inna. Dotychczasowe opracowania tego tematu wysuwają zgodnie na plan pierwszy twórczość Czesława Miłosza, który awansował na patrona „poezji uważnej”. Dominująca rola

M. Głow ińs ki, Epifania. „Kwartalnik Artystyczny” 2014, nr 1, s. 169.

Z. Kró 1, Powrót do świata. Dzieje uwagi $w$ filozofii i literaturze XX wieku. Warszawa 2013. Pada tu na początku następująca definicja uwagi: „określa ona relację podmiotu i przedmiotu, w której: podmiot percypuje przedmiot(y) (często - widzi); przeprowadza percepcję świadomie lub/i jest przekonany o ważności procesu percepcji; oraz wierzy, że to, co postrzega, jest takie właśnie, jak przedstawia się zmysłom (wiara postrzeżeniowa). [...] przekonanie o ważności percepcji wiąże się [...] z uznaniem pracy uwagi za istotny akt inwentaryzacji świata, potwierdzania przedmiotu w jego istnieniu, a nawet, w poetyckiej wersji uwagi - ocalania przedmiotu przed działaniem przemijania; wiara, że to, co się widzi, jest takie, jak się jawi - rozszerza się na wiarę w istnienie rzeczy także poza percepcją, czyli obiektywnie" (s. 10). 
Miłosza jako „poety uważności”, operującego „strategią uważności” została przekonująco udokumentowana m.in. w publikacjach Marka Zaleskiego, Beaty Śniecikowskiej, Kariny Jarzyńskiej3 ${ }^{3}$.

Chciałabym zwrócić uwagę na pewien aspekt problematyki uważności, który wydaje się ciagle niedoszacowany w obrazie kultury XX i XXI wieku. Wyjście poza ramy literatury, a w szczególności poezji oraz przywoływanych przy tej okazji nurtów filozofii pozwoli zobaczyć uważność w perspektywie praxis jako zagadnienie praktykowania uważności w szerszej przestrzeni kultury. Ten wymiar uważności uwidacznia się niewątpliwie także w wypowiedziach poetyckich i dyskursywnych Miłosza i będą tu one nieodzownym punktem odniesienia. Główny wątek tych rozważań wiąże się jednak z postacią malarza i pisarza, niezwykłego człowieka, przyjaciela Miłosza - Józefa Czapskiego ${ }^{4}$.

\section{Uważność/mindfulness}

Czesław Miłosz w Piesku przydrożnym pisał tak o uważności:

Według książki buddyjskiego mnicha, którą czytam, samą istotą buddyzmu jest mindfulness. Chyba można to przetłumaczyć jako u wa żn o ść (słowo jest już u Mikołaja Reja) albo by c i e u ważny m. Znaczy to przyjmować z uwagą to, co jest te ra z, zamiast zwracać się ku temu, co było, albo do tego, co będzie. Zbawienne dla męczenników sumienia, przeżuwających swoje dawne upadki, zbawienne dla niespokojnych, wyobrażających sobie ze strachem, co zdarzy sie jutro. Oby moje wiersze pomogły ich czytelnikowi zamieszkać w teraz. I obym jako człowiek został wyleczony z chorób pamięci ${ }^{5}$.

W doświadczeniu językowym i kulturowym Miłosza słowo „uważność” miało znaczenie, jakim obrosło na przestrzeni wieków w tradycji europejskiej i tej wywodzącej się ze Wschodu. W przywołanym tekście autor wydobył przede wszystkim sens konsolacji i nadzieję apokatastazy, jakie uważność może przynieść poecie ,jako człowiekowi” i jego słuchaczom. Książka buddyjskiego mnicha, która była źródłem inspiracji Miłosza, przypomina o jego rozległych zainteresowaniach religiami Wschodu, a także New Age. Zanim ukazał się Piesek przydrożny, Miłosz dał wiele świadectw tego, jakim był wnikliwym obserwatorem współczesnej kultury; w różnych formach alternatywnej kultury amerykańskiej wypatrywał „znaków nadchodzacych czasów”6. A zatem wiedział, być może, jaką karierę robiło wtedy mindfulness w psychologii rozwoju i w kulturze masowej, choć apogeum tej światowej popularności przypada na pierwsze dekady XXI wieku.

Mindfulness, traktowane dotąd jako rdzeń buddyjskiej medytacji i odnoszone przede wszystkim do tej tradycji, w latach siedemdziesiątych XX wieku dzięki teo-

M. Za le s ki, Od „grzechu anielstwa” do „uważności”, czyli poezja jako instalowanie się w świecie. „Teksty Drugie” 2011, nr 5. - B. Śn i e cik ow sk a, Haiku po polsku. Genologia w perspektywie transkulturowej. Toruń 2016. - K. J a rzy ń s k a, Literatura jako ćwiczenie duchowe. Dzieło Czesława Miłosza w perspektywie postsekularnej. Kraków 2018.

4 Zob. m.in. A. Fiut, Powinowactwa nie tylko z wyboru: Józef Czapski i Czesław Miłosz. W zb.: Granit i tęcza. Dzieła i osobowość Józefa Czapskiego. Red. A. Pilc h, A. Wło d a r c zy k. Kraków 2018.

5 Cz. Miłos z, Uważność. W: Piesek przydrożny. Kraków 1997, s. 19.

6 Jarzyńska, op. cit., s. 340. 
riom i praktyce klinicznej Jona Kabat-Zinna stało się jednym z kluczowych zagadnień współczesnej psychologii i psychiatrii ${ }^{7}$. Mindfulness rozumiane jako metoda zarządzania emocjami funkcjonuje dziś na różnych pułapach wiedzy i kultury. Badania kliniczne prowadzone przez neurologów i psychologów zrodziły wiele nurtów terapii dotyczących całej gamy schorzeń (od depresji i uzależnień po zaburzenia seksualne) ${ }^{8}$.

Wszystko, co funkcjonuje w obecnej kulturze rozwoju osobistego, ma jednak bardzo zróżnicowany stopień profesjonalności. Rychło okazało się, że mindfulness łatwo ulega machinie komercjalizacji, a sfera biznesu jest obszarem wyjątkowo chłonnym dla korzyści płynących z praktyk zwiększających efektywność pracy. Powstało słowo „McMindfulness”, akcentujące uproszczony i globalny charakter proponowanych przez powstające $\mathrm{w}$ całym świecie i popularyzowane przez media nieskomplikowane techniki, zmierzające do osiagnięcia życiowego i zawodowego sukcesu. Mindfulness w wersji light wkroczyło do współczesnej „popnauki” i popkultury. Wielonakładowe podręczniki, programy video, kursy treningowe zyskuja ogromny popyt, trafiając w indywidualne zapotrzebowanie na wszelkiego rodzaju terapie bądź przyspieszone kursy kreatywności. Przygotowanie do „uważnego życia”, pożytki płynące $z$ uważności i w końcu rady dotyczace „praktykowania uważności” znajdziemy we wszystkich materiałach pomocniczych opracowanych przez trenerów mindfulness, wykładowców, coachów.

Zestawienie obszaru współczesnej nauki i kultury sygnowanego terminem "mindfulness" z literackim tekstem Miłosza o uważności zmierza do podkreślenia dość oczywistej dialektyki różnic i podobieństw w obiegach kulturowych. Chciałabym potraktować myśl Miłosza jako reprezentatywną dla dominującego w nowoczesnej sztuce poglądu o wieloaspektowej kulturowej roli uważności, mocno osadzonej w koncepcjach estetycznych poznania, tradycji ćwiczeń duchowych i poetykach epifanii. Takie pojęcie uważności było znaczącym składnikiem kultury wysokiej modernizmu. Mindfulness zaś stało się jednym $\mathrm{z}$ istotniejszych narzędzi autodeskrypcji pewnych nurtów kultury popularnej i nauki przełomu XX i XXI wieku. Związek tych dwóch obiegów można diagnozować co najmniej na dwa sposoby. Jedna interpretacja będzie zmierzać do ujęcia zjawiska mindfulness w kategoriach wulgaryzacji kultury wysokiej czy komercjalizacji sfery duchowej. Problem adaptacji kategorii o proweniencji teologicznej przez kulturę masową to wątek wielokrotnie przez Miłosza podejmowany w kontekście formułowanego przez niego przekonania o postępującym procesie erozji wyobraźni religijnej ${ }^{9}$. Druga interpretacja,

7 J. Ka b a t-Zin n, z wykształcenia mikrobiolog, syn lekarza i malarki, w 1979 r. powołał pierwszy Instytut Mindfulness jako placówkę medyczną w szpitalu uniwersyteckim w Massachusset; prowadziła ona badania nad metodami redukcji stresu, leczeniu stanów lękowych, bólu. Inspirację do klinicznego wykorzystania uważności czerpał z buddyjskiej medytacji i hathajogi, z czasem jednak świadomie ograniczył zakres tych wpływów, koncentrując się w swoich praktykach terapeutycznych na efektywności medycznej.

8 Licznie powstające na całym świecie Instytuty Mindfulness, umocowane często w jednostkach uniwersyteckich, doskonalą dwie główne metody treningu, służące skutecznej terapii: MBSR (Mindfulness-Based Stress Reduction - Program Redukcji Stresu Oparty na Uważności) lub MBCT (Mindfulness-Based Cognitive Therapy - Terapia Poznawcza Oparta na Uważności).

9 Cz. Miłosz w eseju O erozji (w: O podróżach $w$ czasie. Wybór, oprac., wstęp J. Gro m e k. Kra- 
wynikająca $\mathrm{z}$ myśli postsekularnej, będzie raczej dopatrywać się w tym zjawisku prób twórczego włączenia uważności w odnowę życia duchowego. Jedna i druga perspektywa bywa formą silnej waloryzacji kultury; obydwie akcentują możliwość uchwycenia mechanizmów tłumaczących stałą obecność pojęcia i zmienność jego semantycznych i afektywnych funkcji oraz kulturowych instrumentalizacji ${ }^{10}$.

\section{Uważność, czyli lekcja niemożliwego}

Pierwszym nauczycielem uważności dla Józefa Czapskiego był Paul Cézanne. Uczył praktykowania uważności, czyniąc ją podstawowym składnikiem aktywności scalającej proces postrzegania i proces tworzenia. Materiałem do ćwiczeń uważności były zarówno obrazy Cézanne'a, jak i jego wypowiedzi zawarte w listach, wywiadach czy wspomnieniach ${ }^{11}$. Refleksja Czapskiego nad dziełem Cézanne’a prowadziła do odkrywania przeciwieństw i napięć, jakie rodzi postawa uważności. W doświadczeniu estetycznym Czapskiego zakorzenienie uważności w egzystencji i etyce odsłaniało całą skalę niemożliwych do przezwyciężenia sprzeczności.

Uważność Cézanne’a w najbardziej potocznym sensie koncentracji uwagi wyznaczała fazy tworzenia „sur le motif”, w trakcie których dochodziło do częściowego wyłączenia zarówno funkcji życiowych, jak i poczucia odpowiedzialności w sferze moralnej. Jakże przeciwne instynktowi obywatelskiemu Czapskiego było zachowanie Cézanne’a, który na pytanie: „Co Pan robił w siedemdziesiąym roku, podczas wojny?”, odrzekł: „Malowałem pejzaże w Estaque” (C 183). A jednak to właśnie odpowiedzialność staje się kluczową kategorią, jaką stosuje Czapski w odniesieniu do fenomenu osobowości twórczej Cézanne’a:

Cézanne był dla nas wzorem odpowiedzialności w każdym najdrobniejszym wycinku płótna, bo nie było nigdy na płótnie miejsc mniej lub więcej ważnych, a tylko narastająca $z$ latami pełnia i jedyna dźwięczność. [C 367]

ków 2004, s. 25) stwierdzał: „sztuka i literatura należą dzisiaj do tego, co nazywa się świat, w przeciwieństwie do sakralnej strefy religii. [...] Wygląda na to, że aby być uznanym za nowoczesnego artystę, trzeba zapłacić utratą wiary, albo nawet zawarciem diabelskiego paktu, jak to opisuje Tomasz Mann w Doktorze Faustusie. Tylko wyjątkowo, po wielu walkach, udaje się pogodzić własną wiare ze sztuką i wtedy otrzymujemy Cztery kwartety T. S. Eliota”.

10 O uważności w kontekście ćwiczeń duchowych w interpretacji kultury nowoczesnej zob. m.in. P. H a d o t: Filozofia jako ćwiczenie duchowe. Przeł. J. D o mań ski. Warszawa 1992; Czym jest filozofia starożytna? Przeł. P. D o m a ń s ki. Przedm. J. D o m ań s ki. Warszawa 2018. Znaczacą pozycją z kręgu tej problematyki jest także książka D. C za i Znaki szczególne. Antropologia jako ćwiczenie duchowe (Kraków 2013). Problematyce ćwiczeń duchowych w twórczości Miłosza poświęca osobny rozdział J arzyńska (op. cit.).

11 Zob. J. Cza p s ki, Patrzac. Wybór, przedm., posł. J. Polla kówn a. Kraków 2016, s. 62: „Zdziwiłby się, kto nie zna bliżej świata malarskiego, jak pewne powiedzenia Cézanne’a, uwagi i myśli, tylokrotnie dyskutowane i cytowane, wrosły w krew artystów malarzy dzisiejszych, pozornie tak od siebie dalekich”. Dalej do pozycji tej odsyłam skrótem P. Inne publikacje J. C zap skiego oznaczam następująco: C = Czytając. Wybór, oprac., wstęp J. Zi elińs k i. Kraków 2015; PZL = J. C za p s ki, Pamiętając. „Zeszyty Literackie” nry 44-45 (1993, nr $4-1994$, nr 1); WS = Wyrwane strony. Oprac. J. Poll a kó w n a, przy współpr. P. Kł o c z o w s k i e go. [Paris-Lausanne] 1993. Ponadto stosuję skrót S = P. Sloter dij k, Musisz życie swe odmienić. $O$ antropotechnice. Przeł. J. Janiszewski. Wstęp A. Ży chiński. Warszawa 2014. Liczby po skrótach wskazują stronice. 
Radykalne podporządkowanie życia pracy twórczej, skoncentrowanej na ponawianiu prób „dotknięcia samych korzeni bytu, nieuchwytnego źródła wrażeń” i przemienieniu się artysty w „Światłoczuła płytę” ${ }^{2}$, postrzegał Czapski jako działania mające na celu osiągnięcie doskonałości. Widział w tym równocześnie „naiwność i głupotę"13 (bo czyż można kiedykolwiek osiaggnąc cel...), jak i oczyszczającą ascezę, która sprawiła, że Cézanne’a już za życia otaczała aura świętości. Przechodzenie artysty przez kolejne fazy kontemplacji natury porównywał do stanów ekstazy mistyków (przede wszystkim św. Jana od Krzyża) ${ }^{14}$, uważając, że:

Przemyślenie, przeprowadzenie analogii między kontemplacją religijną a na przykład kontemplacją cézanne’owską mogłoby być punktem wyjścia, wykorzystania dla sztuki całej skarbnicy wiedzy o kontemplacji, którą znaleźć możemy w literaturze mistycznej. [P 113]

Nie tylko doskonałość, ale nawet celowość są nieosiagalne w praktykowaniu uważności, mającej trzy wektory: skierowane na przedmiot poznania, na przedmiot tworzenia i zarazem na ,ja” dążące do przemiany wewnętrznej. Ten trzyelementowy układ sił pojawiający się w sytuacji, gdy podmiotem jest artysta, decyduje o partykularności praktykowania uważności w sferze sztuki. Oczywiście, takiej sztuki, która zakłada istnienie Realnego i uznaje odniesienie do niego za istotna wartość.

Problem uważności był zwykle postrzegany w perspektywie relacji temporalnych. Czapski chętnie przywoływał zdanie z listu malarza do Émile’a Bernarda, pisanego rok przed śmiercią: „Teza do rozwinięcia - niezależnie, jaki jest nasz temperament i nasza potęga w obecności natury - dać obraz tego, co widzimy, zapominając wszystko, co się przed nami u ka z a ł o" (P 64). Ta myśl wprowadzała dwa kluczowe zagadnienia o charakterze nieprzekraczalnych aporii. „Teraz”, które jest rdzeniem uważności, odznacza się restrykcyjnością pod względem ontologicznym, artystycznym i etycznym: eliminuje bowiem z horyzontu przeszłość i przyszłość, redukuje pamięć, przynosząc „zbawienie” w empatycznym doświadczeniu jedności $\mathrm{z}$ przedmiotem.

Do takiego aspektu uważności odwoływał się też Miłosz; jego Uważność ewokuje podwójne doświadczenie czasu: w centrum umieszcza epifaniczny błysk, oderwany od tego, co było, i tego, co będzie. Równocześnie, Miłoszowe „teraz” ulega spacjalizacji, jakby promieniuje w głąb - „zamieszkać w teraz” ma szczególny odcień oksymoronu. Czas chwili jest zatem czasem niemożliwym, uważność zagęszcza czas wyrwany z jego wiecznego flux. Miłoszowa uważność nie stanowi przedmiotu refleksji teoretycznej, to dla poety jednak mindfulness, $\mathrm{z}$ jego aspektem praktycznym, to szczególny instrument weryfikacji twórczości jako praxis. Poezja

P. Cézanne, Być światłoczuta ptyta (z rozmów z Joachimem Gasquetem). W: R. M. Rilke, Cézanne. Przeł. A. Serafin. Wstęp A. Zagajewski. Warszawa 2015, s. 101. O fenomenie recepcji myśli i biografii Cézanne’a pisałam w książce Świat artysty. Modernistyczne estetyki tworzenia (Kraków 2018).

14 Zob. P 112-113: „wykres tych stanów [jest] tak nieraz identyczny w swych załamaniach i uniesieniach, w świadomych cofaniach się ku modlitwie bardziej materialnej, że najbardziej świecko nastawiony artysta powinien by się nad tym zastanowić. [...] Chcę być dobrze zrozumiany: nie chodzi mi wcale o sztukę religijną [...]. Chodzi mi o sztukę w ogóle [...]”. 
wyrastająca $z$ uważności powinna mieć moc terapeutyczną: leczyć z chorób pamięci, uzdrawiać męczenników sumienia. A zatem czas inaczej niż w potocznej wiedzy leczy rany - nie przez to, że płynąc stwarza dystans i wymazuje obrazy pamięci, ale dzięki temu, że je wzmacnia, syntetyzuje i translokuje poza doświadczenie zmysłowe i świadomościowe.

Czapski pisząc swój hymn o chwili, postawi też mocny warunek etyczny:

człowiek żyje dzięki sekundom innego wymiaru, czasem dosłownie ułamkiem sekundy [...]. Ale co dają te iskry, co zmieniają, czy o krok posuwają nas czynnie w życiu? [...] Myślę, że te chwile zobowiązują, kiedy ich nie wykorzystujemy, kiedy one się nie odbijają w planach, [...] to my te chwile $\mathrm{zdradzamy.}$ [WS 61]

Dla Czapskiego, zafascynowanego dziełem Cézanne’a, formuła „zamieszkania w teraz" ewokowała dylemat pogodzenia pamięci o mistrzach i tradycji $z$ chwilowością oraz niepowtarzalnością własnego spojrzenia (klasycyzm versus impresjonizm). Oznaczała także, co ciekawsze, zgodę na niedoskonałość estetyczną, niedokończenie, czyli puste miejsce na obrazie, które zyskuje najwyższą wartość autentyczności doświadczenia artysty:

Chodzi tu o sprawę pozornie drobną, a niezmiernie ważna. Cézanne w swoich płótnach nie wahał się zostawiać białych plam, w jego szkicach między każdą plamą widzimy nieraz biel płótna, bo chodziło mu najbardziej o rzetelne położenie farby, każdej plamy, bardziej niż o przekaz tego czy innego pejzażu, tego czy innego portretu. Dla mnie tu się zaczęła lekcja Cézanne’a [...]. [P 423-424]

\section{„Musisz życie swe odmienić”}

Spośród wielu wspomnień o Czapskim, tworzących niebywale rozległą i barwną konstelację portretową, celna uwaga Jeanne Hersch jest godna przypomnienia. Ta uczennica Heideggera i Jaspersa, przyjaciółka i tłumaczka Miłosza, w swojej książce Eclairer l'Obscur (1986) pisała:

Kiedy poznałam Czapskiego w 1948, od razu zrozumiałam, co to za człowiek. Ten malarz, rysownik i pisarz jest postacią wyjątkową. Nie spotkałam nigdy kogoś, kto sięgając tak bardzo w głąb siebie, tyle pracowałby nad sobą. Jest w nim jakiś rodzaj otwarcia, zgoda na przenikanie wszelkiej myśli i doświadczenia do samej głębi jego istoty i zdolność do ich transformacji. W Nowych poezjach Rilkego jest taki wiersz, który nazywa się Starożytny tors Apolla. Poeta opisuje antyczny tors w sposób doskonale plastyczny i nieoczekiwanie kończy opis wersem: „Du musst dein Leben ändern”, „M u s is z tw oj e ży ci e zmienić". Wszystkie doznania Czapskiego z zakresu kultury prowadza do tego imperatywu. Posiada zupełnie jedyny talent uwagi i odbioru; nie mówiąc już o jego zachowaniu się wobec innych i zdolności cierpienia dla innych, nieporównanie żywszej niż u większości ludzi. I ten rodzaj wrażliwości trzeba mu było złączyć z życiem nieprawdopodobnie poddanym wydarzeniom naszego wieku. [PZL 132-133; podkreśl. M. P.]

Ten trop interpretacji fenomenu Czapskiego wydaje się szczególnie trafny w kontekście problematyki uważności. Przywołajmy dwa teksty filozoficzne, które także uruchamiają frazę Rilkego.

Hans Georg Gadamer napisał w połowie lat pięćdziesiątych XX wieku artykuł Rainera Marii Rilkego interpretacja istnienia, rozpoczynający się od stwierdzenia:

Poezja Rilkego stanowi nie tylko przedmiot badań literackich, ale jest dla dzisiejszego człowieka 
przedmiotem prawdziwie filozoficznym [...] - pobudką do autorefleksji i dyskusji z wizją świata, jaką podsuwa poeta ${ }^{15}$.

Sam Gadamer w wielu swoich tekstach nie tylko analizuje i komentuje Rilkego, ale często wypowiada się słowami Rilkego, anektując je do własnego dyskursu bez żadnego sygnału dystansu wobec cudzego słowa; fundamentalny szkic Estetyka $i$ hermeneutyka zamyka frazą:

W dziele sztuki stykamy się z czymś bliskim, a jednocześnie to zetknięcie w zagadkowy sposób wstrząsa nami i burzy zwyczajność. W radosnej i strasznej grozie dzieło sztuki oznajmia: To jesteś ty ale mówi także: Musisz zmienić swoje życie ${ }^{16}$.

Gadamer nie mógł przewidzieć, że ten jeden wers Rilkego będzie brzmiał przez kolejne dekady w uszach wielu filozofów i artystów, stając się wyjątkowo rozpoznawalnym i komentowanym przedmiotem filozoficznym. Pół wieku później potrafił to już zaświadczyć współczesny filozof Peter Sloterdijk; swoją kontrowersyjną książkę Musisz życie swe odmienić. O antropotechnice (2009) poświęcił przedstawieniu koncepcji nowego modelu człowieka: człowieka ćwiczącego, trenującego, homo repetitivus, homo artista. Rozpoczyna ją od wnikliwej analizy wiersza Rilkego Archaiczny tors Apolla, w pełni świadom rytualnego zgoła czerpania ze słów poety:

ostatnie dwa wersy sonetu pociagały za sobą czytelnika od zawsze. Budzą one poczucie doniosłości, przez co uwalniają do lotu cały utwór liryczny - jakby był on tylko wehikułem unoszącym nas ku szczytom punktu kulminacyjnego, stworzonym tylko dla niego. Dwa ostatnie wersy: „każdy atom głazu / widzi cię. Musisz życie swe odmienić”, zrobiły faktycznie karierę niemal niezależną od reszty utworu i zapadły głęboko w pamięć nie tylko wielbicielom Rilkego i liryki, ale ludziom wykształconym w ogóle. $[\ldots]$

[...] Nie trzeba być koniecznie marzycielem, żeby zrozumieć, dlaczego właśnie dwa końcowe zdania rozwinęły niezależne życie. W swojej gruntownej zwięzłości i mistycznej prostocie promieniują jakąś ewangeliczną energią, której nie dostrzeżemy w prawie żadnym innym sformułowaniu nowszej sztuki języka. [S 32-33]

Według Sloterdijka kluczowym momentem utworu jest przejście od wypełniającej prawie cały wiersz części ekfrastycznej do końcowego wezwania. Opis torsu Apolla ewokuje doskonałość nowego rodzaju, wywodzącą się z formy kalekiej i surowej, natomiast najbardziej sugestywne ostatnie dwa wersy z ogromną siłą apelatywna „artykułuja pełne zdanie bytu” (S 31). To ontologiczne przesłanie rzeźby mówi mocniejszym głosem niż jej wymiar boskiej apollińsko-dionizyjskiej reprezentacji. Imperatyw ostatniego zdania Sloterdijk postrzega jako „estetyzujący przekład etyki” (S 35), „imperatyw absolutny - metanoetyczny rozkaz rozkazów” (S 36). Zmierza jednak przede wszystkim w stronę interpretacji, której centralna teza dotyczy somatyzacji i despirytualizacji ascezy oraz wszelkiego typu „napięć wertykalnych” we współczesnej kulturze. Jego przekład i egzegeza formuły „Musisz życie

H.-G. G a d a m er, Rainera Marii Rilkego interpretacja istnienia. W: Rozum, słowo, dzieje. Szkice wybrane. Wybór, oprac., wstęp K. Michalski. Przeł. M. Łukasiewicz, K. Michalski. Warszawa 2000, s. 240-241. 
swe odmienić" odwołując się, nie tylko retorycznie, do perswazyjnego stylu współczesnych trenerów mindfulness, brzmi:

Wyzbądź się swego przywiązania do wygodnego życia - pokaż się w gimnazjum (gymnos, nagi), dowiedź, że nie jest ci obojętna różnica między doskonałym a niedoskonałym, zademonstruj, że osiągnięcie - znakomitość, areté, virtù - nie są dla ciebie obcymi słowami, przyznaj, że istnieją dla ciebie motywacje do nowych wysiłków! Przede wszystkim: podejrzenie, że sport jest tylko sprawą dla głupków, dopuść tylko w tym stopniu, w jakim jest ono rzeczywiście uzasadnione [...]; nie ufaj filistrowi w tobie, który twierdzi, że jesteś w porządku taki, jaki jesteś! Usłysz głos dochodzący z kamienia, nie sprzeciwiaj się wezwaniu do formy! Nie przegap okazji trenowania $z$ bogiem! [S 39-40]

Funkcjonujące współcześnie nurty mindfulness i antropotechniki proponują określone praktyki kulturowe, odpowiadające potrzebom i oczekiwaniom uczestników kultury. Anektują one starożytne i nowoczesne, teologiczne i świeckie tradycje „troski o siebie”. Sięgają także, jak sądzę, do sfery doświadczeń estetycznych, czerpiąc inspiracje płynące z praktyk artystycznych. Koncepcji „człowieka ćwiczącego" Sloterdijka patronuje artysta i akrobata. Uważność i ćwiczenia duchowe stanowią szczególna jedność aktywności podmiotu według wspomnianej zasady triadycznego układu sił: ,ja”, przedmiot poznania i przedmiot kreacji. Artyści nowoczesnej kultury wysokiej dostarczają mikromodeli dla tego rodzaju najnowszych projektów kulturowych.

\section{„Kultura jest regułą zakonną"}

„Kultura jest reguła zakonną" - to Sloterdijk przypomniał owo zagadkowe sformułowanie 60-letniego Ludwiga Wittgensteina. Niezależnie od znaczenia, jakie przypisał temu zdaniu twórca ponowoczesnej antropotechniki, stanowi ono intrygujacy klucz do kultury ascezy i obowiązującej w niej „etyki redukcji”.

\section{Kolekcjoner literatury mąrościowej}

Gadamer czytał poezje Rilkego jako literaturę mądrościową, szukając w niej inspiracji filozoficznych. Wydaje się, że nowocześni artyści poszukujący mądrości - odnajdywali ja przede wszystkim u innych artystów; zarówno wybór lektury, jak i styl jej percepcji jest bowiem zazwyczaj naznaczony szczególnym piętnem pragmatyzmu, nieczęsto stanowiącego cechę postawy filozoficznej. Pragmatyzmu wynikającego z takiego stosunku ,ja” do przedmiotu, który zakłada przekształcenie artystyczne rzeczywistego, oraz wpisującą się $\mathrm{w}$ nie wewnętrzną przemianę podmiotu przed, w trakcie i/lub po akcie tworzenia.

Czapski pozostawił po sobie 250 kajetów Dziennika, a także eseje, wspomnienia, listy; był również zapalonym czytelnikiem wszelkiego rodzaju dokumentów osobistych. O tym, jaką rolę odgrywają pamiętniki, dzienniki, listy malarzy, pisał przy okazji edycji Pamiętnika Tadeusza Makowskiego w 1961 roku. Ubolewał nad brakiem tradycji kultywowania „klimatu myśli malarskiej” w polskiej literaturze, wskazując na chwalebny wyjątek Stanisława Witkiewicza: „Zawsze uderzało mnie, jak mało mamy w naszym malarstwie bezpośrednich dokumentów tradycji, dzienników, tekstów malarskich pisanych przez malarzy, listów" (WS 37). Wypowiadając się w imieniu swojego pokolenia i kręgu znanych mu osób, przekonywał, jak nikłe 
znaczenie miały dla nich teksty historyków i krytyków sztuki w przeciwieństwie do tego, co „pisali, myśleli i wypowiadali” artyści:

Nie było chyba nikogo wśród nas, kto by nie czerpał z francuskiego dziewiętnastego wieku od Dziennika Delacroix, poprzez Fromentina, Odilon Redona, Pissara, po listy van Gogha, pisma Gauguina - każde słowo z każdego listu i każdej wypowiedzi Cézanne’a po boutades Picassa i jemu współczesnych. Ileż dla me dy ta cji mala rs ki ej, dla rzemiosła malarskiego dają Dzienniki i inne teksty Delacroix po świeżo wydanego Jean Colin. Jakie dają poczucie wspólnoty, jak każdy z nich nieraz nawet wielokrotnie nawraca do swoich momentów wahania, bezsilności, nadziei [...]. [WS 37; podkreśl. M. P.]

Literatura mądrościowa, jakiej szuka artysta, jest literatura „użytkową" nie dlatego, że uczy rzemiosła, ale przede wszystkim dlatego, że służy „medytacji”, warunkującej w jakiś szczególny sposób tworzenie. Cała sfera osobowości $z$ jej energia, siła kreacji, emocjami, wyobraźnia żywiła się tym swoistym „poczuciem wspólnoty" rodziny artystów, która komunikowała się ze sobą zarówno przez malarskie artefakty, jak i przez świadectwa tekstowe przekraczające bariery czasu i miejsca.

Więź, jaka rodziła się w lekturze dokumentów osobistych, obejmowała nie tylko malarzy czy artystów w ogóle. Czapski był kolekcjonerem „książek-wyznań”, nasyconych żywą materią konkretnej biografii. Wielokrotnie powraca w jego wypowiedziach zdanie z Pamiętnika Stanisława Brzozowskiego, mające moc silnego argumentu: „co nie jest biografią - nie jest w ogóle”. Wybierane przez Czapskiego lektury wpisywały się w fundamentalną regułę „Musisz życie swe odmienić”. W szkicu zatytułowanym $J a$, poświęconym przede wszystkim dziennikom Maine de Birana deklaruje, iż owe „książki-wyznania” odczuwa jak część własnej biografii: „Te dzienniki, te kartki z notatników, francuskie, polskie, rosyjskie, k a rmiły mnie, uczyły, towarzyszyły wewnętrznie, upokarzały czy dodawały otuchy" (C 142) ${ }^{17}$.

Etyka redukcji każe okrawać teksty literackie do najbardziej pożytecznych cytatów, stających się „złotymi gwoździami”, „które trzymają w życiu naprawdę”18. Uważność lektury przypomina koncentrację sił umysłowych i mięśni rybaka, gotowego, dzięki czujności, wyłowić z zalewu słów najcenniejszy okaz.

Wycięte $z$ całości utworu fragmenty zaczynają żyć w pamięci Czapskiego, stając się partnerami w myśleniu i tworzeniu, dając nadzieję, podsycając pragnienie aktywności. Te słowa zapisane cudzą ręką ożywają dzięki uważności czytelnika, ale i bricoleura, który je wybrał, przykroił do swoich potrzeb i - często - zestawił z innymi cudzymi słowami, aby zyskały wartość blasku chwili. W tych, wydawałoby się, racjonalnych wyborach dominuje mechanizm swoistej wersji Proustowskiej memoire involontaire. Początkowo Czapski był kolekcjonerem cytatów, mógł tworzyć wypisy z europejskich „ksiąg użytecznych”, zapamiętanych zazwyczaj w oryginale.

M. J a ni o n w eseju Dziwaczny wzrost (w zb.: Czapski i krytycy. Antologia tekstów. Wybór, oprac. M. Kitowska-Łysiak, M. Ujma. Lublin 1996, s. 337) zasadniczy rys intymnego pisarstwa Czapskiego ujęła tak: „Dziennik Czapskiego to niejako protokoły walki o "świadomość życia" w sztuce, o uzyskanie spotęgowania tej świadomości. Dzieje się to w aurze pełnej poczucia odpowiedzialności, że się nie dopuściło żadnej zdrady. Gdyż "świadomość życia" w sztuce jest dla Czapskiego przede wszystkim kategorią etyczną".

W. Kar piń s ki, Złote gwoździe. W: Portret Czapskiego. Warszawa 2015, s. 108. 
Z czasem przestrzeń tych tekstowych rozbłysków kurczy się, lecz także nabiera jeszcze większej mocy epifanii:

Skąd naraz - „ten trud, co mnie zabijał” - strzępy strzępów Wyspiańskiego! Jego wiersze? Jego sztuki? Ależ nie, to on sam, ta jego „mowa własna”, otaczające go maski [...].

Więc co? Już nie strzępy wierszy, coraz to nieściśle sobie powtarzane, ale słowa wyrwane są mi bliższe niż Miłosz, niż Zbyszek Herbert [...]. Naraz wracają mi te teksty, nie teksty, słowa, ta garść, garsteczka. [...]

$[\ldots]$

Co zostaje naprawdę, to „poezja i dobroć”. Może tak właśnie jest dobrze, i te moje strzępy słów, które budzą inne i inne skrawki zdań. Denn das Schöne ist nichts als des Schrecklichen Anfang ${ }^{19}$, w wierszu Rilkego [...]. [WS 162-163]

Te strzępy strzępów słów znajdują u Czapskiego rychło swój odpowiednik w fantazji malarskiej; wyświechtany, banalny i nachalnie patetyczny wizerunek Rembrandta przy pracy, otoczonego duchami innych artystów, śledzących każdy ruch jego ręki, zyskuje walor obrazu archetypowego, ciagle i od nowa przemawiającego do wyobraźni twórcy. Uważność ma nie tylko moc oświetlania tego, co nowe i pierwszy raz ujrzane, ale magię reaktywacji. Słowa i obrazy zrodzone $z$ uwagi tworzą najbardziej podniosłą formę uważności, którą Simone Weil nazywała modlitwą ${ }^{20}$. Słowa i obrazy pielęgnowane w naszej pamięci tworza „ewngeliczny” tekst naszego życia - do niego Czapski wracał w rytualnych praktykach odnawianej świadomości.

Dla Czapskiego niezbędne w „sztuce życia” są „złote gwoździe”, a dla Miłosza „kapsułki energii”. Takie określenie pojawia się we wstępie do zbioru poezji Jane Hirshfield zatytułowanego Uważność:

W tym początku XXI wieku pisze się mnóstwo poezji i o poezji. Kto wie, czy to rzemiosło nie dostarcza utworów, które stanowią część sztuki życia. Nie jest to ani wiedza naukowa, ani filozofia, może po prostu jakieś utrwalone kapsułki energii przekazywane za pośrednictwem kartek. I w rezultacie coś bardzo zbliżonego do modlitwy ${ }^{21}$.

\section{Somatyzacja ascezy: uważność i oddech}

Pragnienie uważności przenika całe długie życie Czapskiego; uważność była warunkiem uczestniczenia we wszystkich sferach życia artystycznego, towarzyskiego, politycznego, które się ze sobą tak ściśle, a czasem paradoksalnie splatały.

Książki-cytaty-strzępki - to znaki kurczącej się wraz z upływem czasu kulturowej przestrzeni uważności Czapskiego. Naturalny proces przynoszący kolejne stopnie ograniczeń jest stałym motywem zapisów w Dzienniku przez kilka dekad. Już w 1965 roku, a zatem mając 69 lat, pisarz wnikliwie badał zmiany, jakie na jego uważności wymuszał czas:

Starość: wzrost godzin bezmyślnych, godzin nieistnienia? Czy koniecznie? Wysiłek, żeby żyć, żeby chodzić, kiedy boli krzyż, żeby zdążyć i wszystko zapamiętać, kiedy słabnie pamięć, kiedy rosną lu ki w uwadze, kiedy rośnie potrzeba odpoczynku, samotności, a jednocześnie nie wygasł głód obcowania,

19 W przypisie podano tłumaczenie: „Piękno bowiem jest jedynie przerażenia początkiem”.

20 Cz. Miło s z przetłumaczył tę słynną frazę S. Weil tak: „Uwaga absolutna bez domieszki jest modlitwą" (S. Weil, Wybór pism. Przeł., oprac. Cz. Miłos z. Kraków 1991, s. 147).

21 Cz. Miłos z, wstęp w: J. Hirs hfield, Uważność. Przeł. M. Heydel. Kraków 2002, s. 7. 
kiedy imaginacja, pragnienia są młodsze od ciała, które już trzeba dźwigać. Ale w zamian myśl może być głębsza - doświadczenie lat pracy i przecież myśli, lat ży ci a [...]. Ale trzeba nie dawać się unieść imaginacji, wiedzieć, na co cię stać i na co nie, ograniczać się. [...]

$[\ldots]$

[...] Starość to świadomość, ale ona jest na coś zdatna tylko, jeżeli się z niej wyciaga precyzyjne wnioski, na początku pracy jakby naraz narośnięcie os trości widzenia i całościowości widzenia postęp. Ale jak szybko upadek uwagi. [PZL 30-31]

Miara pożądania stanu napięcia uwagi są emocje, jakie towarzyszą poczuciu niemożności osiągnięcia go. Związane $z$ tym wypowiedzi najbardziej przejmująco brzmią w ostatnich, $z$ trudem odszyfrowanych przez bliskich, zapiskach Czapskiego z 1993 roku. Uwaga, jakiej wymaga sama egzystencja projektowana według określonych reguł, w ostatnich latach słabła; trudności w prowadzeniu Dziennika, formułowaniu myśli mówią o skali cierpienia i wysiłku sprostania wyzwaniom:

Jestem znikąd dziś! Jestem nieprzemijająca pauza. [...] Zaczynam znikąd i donikąd. Niedziela ze zgubionym kajetem. [...] Coraz mi trudniej myśleć. Gdzie ja, ten naprawdę? Paciorki się rozsypały. [...]

$[\ldots]$

[...] Pomieszałem numery ostatnich dzienników, co jest równoznaczne zagubieniu ciągłości w sobie. [PZL 6; podkreśl. M. P.]

Czapski zdaje sobie wówczas sprawę, że „kontemplacja może być niekoniecznie bezinteresowna” (PZL 7), staje się bowiem orężem w walce o przedłużenie funkcji egzystencjalnych, które uznało się za najważniejsze. To czas, gdy bardziej niż kiedykolwiek praca intelektu przypomina oddychanie: bywa, że nabieranie powietrza jest coraz trudniejsze, lecz nie sposób go zatrzymać: „Chcę, żeby tok moich myśli wysechł, ale ten... [...] Czy to uczciwe pisanie? Autentyczność i nieświadomość” (PZL 8). Tej jedności fizjologicznych uwarunkowań organizmu $\mathrm{z}$ aktywnością duchową i intelektualną Czapski był zawsze świadom:

Pisanie dziennika w miarę lat staje się oddechem i z natury rzeczy „oddychamy” nie według planu, piszemy, o czym myślimy, co odczuwamy z chwili na chwilę, bez ustalonej z góry hierarchii ważności (kieruje nami tylko mniejsza lub większa siła przeżycia w chwili pisania, a nie logika i to, to jest dziennik: ile tam zainteresowania soba, swoim ciałem, swoim nastrojem!). [WS 93]

Wojciech Karpiński wspominając swoje rozmowy z Czapskim i wypowiadane przez niego frazy, przywołał tę dobrze zapamiętaną, jedną z ostatnich usłyszanych od przyjaciela - swoisty autokomentarz do całego dzieła życia: „Opowiadałem swój oddech" (PZL 45).

Nie tylko pisanie, także rysowanie miało dla Czapskiego funkcję oddychania:

Moja radość życia? Chyba to słowo znaczy: wola życia, pracy po odnalezieniu się w samotności, i wyraża się w tym, że znowu oddycham swoim oddechem, znowu widzę, oddycham oczami. [WS 83]

Te dwie podstawowe aktywności: pisanie i rysowanie, biegnące równolegle na kartach Dziennika w tym szczególnym uzdolnieniu Doppelbegabung mają znaczenie funkcji życiowych, biologicznych i duchowych.

Podobny obraz somatyzacji procesu tworzenia znajdziemy u Miłosza. Marek Zaleski w interesującym szkicu Od „grzechu anielstwa” do „uważności”, czyli poezja jako instalowanie się $w$ świecie przywołuje jedna $z$ ostatnich fraz poety: „Zapisy mego czucia, że żyję, oddycham. Tym były moje wiersze, więc hymnami wdzięcz- 
ności. A zarazem z tym byłem świadomy nieszczęścia, skaleczenia”22, jak też tę ważną deklarację:

Poezja jest energią. Otóż istnieje we wszechświecie tajemnicze wspólnictwo pomiędzy energią, ruchem, rozumem, życiem i zdrowiem. Czy są pesymistyczne czy optymistyczne, wiersze są zawsze pisane przeciwko śmierci ${ }^{23}$.

Czapski powiedziałby, że nie tylko przeciwko śmierci, także przeciw acedii martwocie za życia. Ten wątek refleksji zarówno u Czapskiego, jak i u Miłosza ma wspólnego przewodnika w osobie Simone Weil. Czapski wielokrotnie, jakby zadziwiając siebie samego, potwierdzał wpływ jej myśli, które wydobywały go z marazmu, słabości, zmęczenia. W Dzienniku z 11 stycznia 1970 „po pracy”, w poczuciu znalezienia się „w ciemności” sięga do korespondencji Weil, cytując jej słowa:

żyłam i pracowałam z codziennym uczuciem, że moje intelektualne możliwości były literalnie w przededniu zupełnego wygaśnięcia... ale są skarby miłosierdzia dla tych, którzy pragną prawdy. Nie mogą oni pozostawać w ciemności. Ale w zamian za to miłosierdzie jest obowiązek wszystko podeptać (piétiner) w sobie samym prędzej, niż ścierpieć, niż przyjąć przeszkodę, zgodzić się z jakąkolwiek przeszkodą na drodze ku prawdzie. [PZL 39]

Emocjonalny komentarz Czapskiego do tych słów rozpoczyna się tak:

Dlaczego, dlaczego ta szalona, ta wariatka, nie Pismo Św. ani Izajasz nie pomagają mi, nie pokrzepiaja, jak ona. Szalona? Wariatka? ale to „piétiner”, to okrucieństwo wobec siebie [...]. [PZL 39] ${ }^{24}$

Imperatyw czujności i energii wypływający ze źródeł metafizycznych bądź przesłanek etycznych zwykle był u Czapskiego przesycony wątpliwościami, sceptycyzmem, niepewnością.

\section{Tresura wewnętrzna}

Przedmiotem uważności dla Czapskiego okazuje się cała rzeczywistość: natura i dzieła sztuki, człowiek, ten Inny i ,ja”, przedmioty i myśli, obrazy i słowa, rzeczy codzienne i sytuacje wyjątkowe w swojej drastyczności oraz te niezwykłe w pięknie. Stan uważności nie jest kontemplacją rzeczywistości percypowanej zmysłowo, jest aktywną postawą czujności wobec świata, nie pozwalającą uronić nic z tego, co zostało nam dane. Czuwanie wymaga stałego pobudzania i samodyscypliny. W całym bogatym życiu Czapskiego krzyżowały się motywacje etyczne, metafizyczne i estetyczne. Głębokie poczucie odpowiedzialności za innych współbrzmiało z ewangelicznym wezwaniem do czujności z przypowieści o Pannach Mądrych i Głupich. Napięcia uwagi wymaga każda chwila, mogąca nagle zmienić się w tę ostateczną. Trzeba wyposażyć się we wszystkie dostępne narzędzia gotowości, by sprostać

24 Te słowa, skierowane do siebie, a będące czesścią trwającego wiele lat dramatycznego sporu z Weil, Czapski także wykrzyczał. Jak opowiada A. Za gaj ew ski w znakomitym i poruszającym eseju Piłowanie i błysk (w zb.: Czapski i krytycy, s. 527), Czapski podczas przedstawienia poświęconego życiu mistyczki uprzedził kwestię aktorki wcielającej się w Simone Weil i z widowni krzyknął „Elle est folle! [Ona jest szalona!]”. 
wyzwaniu gwałtownej odmiany czasu. Czujność wymaga racjonalnych atrybutów, asekuracji, zabiegów zabezpieczających i ograniczających ryzyko niesprostania chwili. Nie leży tylko po stronie instynktu, jest owocem pewnej sprawności, kondycji; ostatnie zdania jednego z tekstów towarzyszących Czapskiemu całe życie, Contre Sainte-Beuve Prousta, brzmi:

Dochodzi się do wieku, kiedy talent słabnie tak jak pamięć; m u s ku 1 u m y s ł u, który uruchamia pamięć wewnętrzną i wspomnienia świata, traci siły. Bywa, że wiek ten trwa całe życie, bo te go mi ieśnia nie ćwiczymy, bo przedwcześnie spoczywamy na laurach... [PZL 143; podkreśl. M. P.]

„Muskuły umysłu” zachowują sprawność dzięki ćwiczeniu się w czujności:

Łaska radości życia, gdzie wszystko może się przemienić w radość, w błogosławienie życia - nie od ciebie zależy. Od ciebie zależy to, co S. W. nazywa dressage (tresura wewnętrzna), która musi być zawsze; i zdolność czekania, ogromna wytrwałość w czekaniu. „Chce mi się” - to jest przecie wola życia, najbardziej uzależniona od wszystkiego, od nastroju, najszybciej przemijająca, na niej jednej nie można nic budować, ją można wykorzystywać, ki edy jest, nic więcej, a do śmierci musi być dressage, nie „mi się chce”, a ,ja chcę” - to jest podstawa. [WS 107]

Owa tresura wewnętrzna dotyczyła treningu uważności. Słowa Weil zapadły Czapskiemu w pamięć tak głęboko, iż stały się miarą jego własnego życia, a także życia wszystkich innych, których gromadził wokół siebie w swojej imaginacyjnej kolekcji słów obrazów. Tak jest np. z jego ulubionym de Biranem:

„[...] nie kłamać i mieć napiętą uwagę" - to zdanie Simone Weil może służyć za epigraf całego życia Birana. Wpatrując się nieustannie w siebie, pisząc ciagle o sobie, ten człowiek o twarzy jak z portretu Greuze’a „nie kłamał i miał zawsze napięta uwagę”. [C 152; podkreśl. M. P.]

Uważność była przez Weil postrzegana nie tylko z perspektywy teologicznej i etycznej, także - wolicjonalnej. Przekonanie o wyższości uważności nad wolą było dla Czapskiego istotnym przesłaniem. Przywołując opinię Gustave’a Thibona ze wstępu do pośmiertnie wydanej La Pesanteur et la grâce skupia się pisarz na zagadkowej frazie $z$ tej książki: „Trzeba być obojętnym na dobro i zło, ale naprawdę obojętnym, to znaczy na jedno i drugie kierować jednakowo światło uwagi". I z wywodów Weil wyciaga fundamentalny wniosek: „Ni e wola, a uwaga może nas pchnać naprzód na drodze rozwoju” (C 151). Uważność to jedna z najbardziej niejasnych i zagadkowych miar, jaką Czapski przykładał do „sztuki życia”. Uważność rozpięta pomiędzy duchem a ciałem, świadomością a nieświadomością, ruchem a bezruchem, należąc do, jak by powiedział Sloterdijk, „uniwersum ludzkich napięć wertykalnych” (S 20), czyniła z Czapskiego „artystę przemienienia”25.

\section{Pokój Czapskiego}

W sztuce, a także w refleksji nad nią w XX wieku ugruntowuje się przekonanie nie tylko o słabnącej aurze dzieła sztuki, ale również o jego zanikającym statusie w świecie artystycznym. W latach sześćdziesiątych zaczęto kwestionować koniecz- 
ność materialnego istnienia artefaktu, do czego sztuka konceptualna starała się dostarczyć argumentów. Równolegle z tym procesem rosło znaczenie wszystkiego, co należało do praktyk „okołoartefaktycznych”.

Wszystkie kolejne kroki podejmowane przez artystę - szkice, rysunki, modele, studia, nieudane bądź porzucone próby, myśli, rozmowy - są interesujące. Pokazują bowiem proces myślowy artysty, który czasami jest ciekawszy niż końcowy produkt.

- powie współczesny estetyk ${ }^{26}$. Ze strony samych artystów płynęły sugestie kierujace zainteresowanie na proces twórczy i podmiot. Literaturoznawstwo z jego nowym spojrzeniem na dokumenty osobiste, krytyka genetyczna, antropologia i socjologia w ciagu ostatnich dekad wzmocniły tę tendencję.

To wszystko, co możemy znaleźć w świecie Józefa Czapskiego - my, którzy nie mieliśmy okazji go znać - staje się dostępne poprzez materię świadectw i spuściznę artystyczną. Jest w Krakowie miejsce dedykowane Józefowi Czapskiemu. Z inicjatywy jego przyjaciół, przede wszystkim Krystyny Zachwatowicz i Andrzeja Wajdy, powstała wyjątkowa przestrzeń nawiązująca do formuły muzeum biograficznego, a jej punkt centralny stanowi niewielkie pomieszczenie, będące rekonstrukcją pokoiku z Maisons-Laffitte, w którym Czapski spędził kilka dekad. Oryginalne meble (nawet okiennice, drzwi i framugi), przedmioty codziennego użytku, sztalugi z niedokończonym obrazem odtwarzają materialną, ascetyczną przestrzeń życiową artysty. Brakuje w niej tylko szczupłej, wysokiej postaci, jak sam żartobliwie mówił, „największego polskiego malarza”. Pokój Czapskiego - zwykłe, zniszczone, wytarte rzeczy, przedmioty „bezkształtne i kalekie”, to „nic”, którego artysta zawsze poszukiwał - dziś „trwa i lśni”. Czy wobec tego miejsca możemy powtórzyć: „każdy atom głazu / widzi cię. Musisz życie swe odmienić?" Czy wrażliwość, wyobraźnia i oczekiwania człowieka początku XXI wieku, odrzucając autorytet arcydzieł, „zamieszkaja w teraz" małego pokoiku i czy to, co w nim usłysza, zabrzmi jak rilkeańskie wezwanie?

\author{
Abstract \\ MAGDALENA POPIEL Jagiellonian University, Cracow \\ ORCID: 0000-0002-0424-2985
}

\title{
PRACTISING MINDFULNESS AND THE CULTURE OF TEMPERANCE ON JÓZEF CZAPSKI
}

The article takes up the subject of mindfulness and sees it as a broad concept that functions in various spheres of culture and scopes of meanings. The author points at the role that mindfulness performs in the artistic and philosophical tradition, as well as in the contemporary developmental psychology and late capitalism culture, and also analyses the reflections on "practising mindfulness" in Józef Czapski's and Czesław Miłosz's creativity. Czapski's Dziennik (Diary) offers a rich material for reconstructing the mindfulness stance as a key aspect of existence, artistic creativity and metaphysical experience. A special place in Czapski's notes is occupied by a somatic approach to the activity of the intellect and the

26 S. Le W it t, Paragraphs of Conceptual Art. W zb.: Esthetics Contemporary. Ed. R. Ko s t e a n e tz. New York 1987, s. 416. Cyt. z: Wizje i re-wizje. Wielka księga estetyki w Polsce. Red. K. Wilk os zew s ka. Kraków 2007, s. 203. 
will. "Practising mindfulness" combines several spheres of activity: intellectual, spiritual, emotional, and somatic. In the present article, the pragmatic aspect of mindfulness is prominently displayed in setting it within the domain of issues in aesthetics of creation.

Discerning mindfulness in the context of "spiritual exercises" tradition leads to the formula of "culture as a monastic rule" (Ludwig Wittgenstein). A source of inspiration for the contemporary reinterpretation of the idea of forming (Bildung) or ancient "care of oneself" is Peter Sloterdijk's publication Du mußt dein Leben ändern (You Must Change Your Life). The Rilkean topos of transformation which it uses is a key to the concept of man and artist that we can infer from the entire Czapski's heritage. 